\title{
Optimasi Multi Objektif Pada Pemilihan Portofolio Saham Syariah Menggunakan Compromise Programming (CP) dan Nadir Compromise Programming (NCP)
}

\author{
Tri Anton Saputro dan Mohammad Farhan Qudratullah \\ Program Studi Matematika Fakultas Sains dan Teknologi, UIN Sunan Kalijaga, JI. Marsda Adisucipto \\ No. 1 Yogyakarta, Indonesia
}

Korespondensi; Tri Anton Saputro, Email: triantonsaputro@gmail.com

\begin{abstract}
Abstrak
Portofolio saham merupakan sekumpulan aset invetasi berupa saham yang dibentuk oleh para investor. Tujuan investor membentuk portofolio antara lain untuk mendapatkan pengembalian atau return yang tinggi dengan risiko yang rendah. Untuk mendapatkan portofolio yang optimal maka dilakukan optimasi pada beberapa faktor investasi yaitu mengoptimalkan risiko, memaksimalkan expected return dan meminimalkan modal investasi. Dalam penelitian ini dilakukan pembentukan portofolio menggunakan metode Compromise Programming (CP) dan Nadir Compromise Programming (NCP).Model CP dibentuk berdasarkan dari kemungkinan solusi terbaik, sedangkan model NCP dibentuk berdasarkan dari kemungkinan solusi terburuk. Hasil dari penelitian ini menunjukkan bahwa metode NCP lebih baik dibandingkan dengan metode CP karena risiko yang optimal dapat diperoleh pada metode NCP.

Kata Kunci: Portofolio Saham; Optimasi Multiobjektif; Compromise Programming; Nadir Compromise Programming

Abstract

The stock portfolio is a set of investment assets in the form of shares formed by investors. The purpose of investors to form a portfolio is to get a high return with low risk. To get an optimal portfolio, optimization is done on several investment factors that are optimizing risk, maximizing expected return and minimizing investment capital. In this research, the formation of a portfolio using Compromise Programming (CP) and Nadir Compromise Programming (NCP) method. The CP model is formed based on the best possible solution, while the NCP model is formed based on the worst possible solution. The results of this research indicate that NCP method is better than CP method because optimal risk can be obtained by the NCP method.
\end{abstract}

Keywords: Stock Portfolio; Multi-objective Optimization; Compromise Programming; Nadir Compromise Programming

\section{Pendahuluan}

Investasi adalah komitmen atas sejumlah dana atau sumber daya lainnya yang dilakukan pada saat ini, dengan tujuan memperoleh sejumlah keuntungan di masa datang [1]. Pihak-pihak yang melakukan investasi disebut dengan investor.Investor dapat melakukan investasi baik dalam sektor riil maupun sektor keuangan.Investasi sektor keuangan yang saat ini sedang diminati banyak kalangan yaitu investasi saham di pasar modal.Saham dapat didefinisikan sebagai tanda penyertaan modal seseorang atau pihak (badan usaha) dalam suatu perusahaan atau perseroan terbatas.Dengan menyertakan modal tersebut, maka pihak tersebut memiliki klaim atas pendapatan perusahaan, klaim atas asset perusahaan, dan berhak hadir dalam Rapat Umum Pemegang Saham (RUPS) [2].

Di Indonesia sendiri terdapat indeks saham syariah yang tergabung dalam Jakarta Islamic Index (JII).JII adalah salah satu indeks saham di Indonesia yang menghitung indeks harga rata-rata saham untuk jenis saham-saham yang memenuhi kriteria syariah. 
Tujuan para investor berinvestasi pastinya ingin mendapatkan return atau pengembalian yang maksimal dengan risiko yang minimal. Untuk mecapai itu investor dapat melakukan diversifikasi atau penyebaran investasi pada beberapa perusahaan dengan membentuk suatu portofolio saham. Portofolio adalah suatu gabungan dari berbagai instrumen atau saham yang disusun untuk mendapatkan keuntungan yang maksimal, jadi jika dirumuskan secara matematis dalam suatu model investasi terdapat dua fungsi tujuan yang dipertimbangkan oleh investor yaitu memaksimalkan return dan meminimalkan risiko [3].

Portofolio dibentuk agar investasinya memberikan keuntungan tertentu dengan risiko yang kecil atau yang dapat ditanggungnya, dengan kata lain portofolio tersebut haruslah portofolio yang optimal dan efisien. Untuk membentuk portofolio yang optimal dan efisien investor harus melakukan analisis terhadap portofolio tersebut. Banyak cara atau teknik analisis yang bisa digunakan salah satunya dengan optimasi multiobjektif.

Dalam jurnal Expert Systems with Applications 38 tahun 2011 hal. 7222-7226 yang berjudul Nadir Compromise Programming: A model for optimization of multi-objective portofolio problemmenjelaskan tentang optimasi portofolio menggunakan metode compromise programming dan nadir compromise programmingpada 35 saham di Iran [4] serta penelitian yang dilakukan oleh Halwa Annisa yang berjudul Perbandingan Compromise Programming dan Nadir Compromise Programming untuk Optimasi Multi-Objective Pada Pemilihan Portofolio Saham yang menjelaskan tentang optimasi portofolio menggunakan metode compromise programming dan nadir compromise programmingpada 25 saham di Indonesia. Dengan latar belakang masalah yang ada serta acuan peneltian sebelumnya penulis mengambil judul Optimasi Multi Objektif Pada Pemilihan Portofolio Saham Syariah Menggunakan Compromise Programming Dan Nadir Compromise Programming .Data yang digunakan pada penelitian ini adalah 30 saham yang terdaftar dalam Jakarta Islamic Index (JII) periode 1 April 2015 sampai 31 Mei 2017.

\section{Landasan Teori}

\section{Saham Syariah}

Saham syariah adalah sertifikat yang menunjukkan bukti kepemilikan suatu perusahaan yang diterbitkan oleh emiten yang kegiatan usaha maupun cara pengelolaannya tidak bertentangan dengan prinsip syariah [5].

\section{Jakarta Islamic Index (III)}

JII adalah salah satu indeks saham di Indonesia yang menghitung indeks harga rata-rata saham untuk jenis saham-saham yang memenuhi kriteria syariah.Jl didirikan untuk meningkatkan kepercayaan investor dalam melakukan investasi pada saham berbasis syariah dan memberikan manfaat bagi pemodal dalam menjalankan syariah Islam dan untuk melakukan investasi di bursa efek [6].

\section{Return dan Expected Return}

Perhitungan return realisasi ini ada dua jenis yaitu diskret dan kontinu. Return diskret dirumuskan sebagai:

$$
R_{t}=\frac{S_{t}-S_{t-1}}{S_{t-1}}
$$

Dengan $R_{t}$ adalah tingkat pengembalian (return) saham saat ke- $t$, dan $S_{t}$ adalah harga saham pada saat ke-t. Sedangkan untuk menghitung return kontinu digunakan rumus:

$$
R_{i}=\ln \left(\frac{S_{i}}{S_{i-1}}\right)
$$

Untuk mencari expected return digunakan rumus: 


$$
E\left(R_{i}\right)=\frac{\sum_{j=1}^{N} R_{i j}}{N}
$$

Dengan $E\left(R_{i}\right)$ adalah return yang diharapkan pada saham $i, R_{i j}$ adalah return saham $i$ pada saat ke$j$ dan seterusnya, dan $N$ adalah jumlah periode melakukan pengamatan.

\section{Variansi dan Standar Deviasi}

Varians merupakan ukuran dalam perhitungan risiko saham dengan melihat return, expected return, dan jumlah periode dilakukan pengamatan harga saham. Varians dari sejumlah $N$ data return, dirumuskan dalam persamaan [7]:

$$
\sigma_{i}^{2}=\sum_{j=1}^{N} \frac{\left(R_{i j}-E\left(R_{i}\right)\right)^{2}}{N}
$$

Dengan $\sigma_{i}^{2}$ adalah nilai varians saham i. Deviasi standar adalah ukuran dalam perhitungan risiko saham dan merupakan akar kuadrat dari varians. Deviasi standar pada saham $i$ dinotasikan dengan $\sigma_{i}$.

\section{Kovarian}

Kovarian adalah pengukur untuk menunjukkan arah pergerakan dari dua variabel. Kovarian dirumuskan sebagai [8]:

$$
\operatorname{Cov}\left(R_{i}, R_{m}\right)=\sum_{j=1}^{N} \frac{\left(R_{i j}-E\left(R_{i}\right)\right)\left(R_{m j}-E\left(R_{m}\right)\right)}{N}
$$

Dengan $R_{i}$ adalah return saham $i$ dan $R_{m}$ adalah return pasar.

\section{Koefisien Risiko (Beta Saham)}

Risiko dalam investasi yang akan ditanggung oleh investor dapat dilihat dari koefisien risiko saham. Untuk mencari koefisien risiko dapat digunakan rumus [8]:

$$
\beta_{i}=\frac{\operatorname{Cov}\left(R_{i} R_{m}\right)}{\sigma_{m}^{2}}
$$

\section{Compromise Programming}

Metode Compromise Programming (CP) diperkenalkan oleh Zeleny pada tahun 1974. Metode CP merupakan sebuah metode yang dapat digunakan untuk menyelesaikan permasalahan multiobjektif untuk mencari solusi kompromi terbaik dalam mengoptimalkan dua atau lebih fungsi objektif.

Fungsi tujuan ke- $k, k \in \mathbb{N}$ pada metode $\mathrm{CP}$ di definisikan sebagai berikut:

$$
\begin{gathered}
f_{k}: S \rightarrow \mathbb{R} \\
f_{k}: x \rightarrow f_{k}(x), \forall_{x} \in S
\end{gathered}
$$

Fungsi tujuan ke- $k$ dari semesta $S$ ke himpunan semua bilangan real $\mathbb{R}$. Selanjutnya untuk penulisan $f_{k}(x)$ disingkat $f_{k}$.

Dalam metode $\mathrm{CP}$, apabila fungsi tujuannya adalah mengoptimalkan $f_{i}$, meminimalkan $f_{j}$, dan memaksimalkan $f_{k}$ secara berturut-turut ditulis [4]:

$$
\text { Optimisasi } f_{i}(i=1,2,3, \ldots, A)
$$




$$
\begin{gathered}
\operatorname{Min} f_{j}(j=1,2,3, \ldots, B) \\
\operatorname{Max} f_{k}(k=1,2,3, \ldots, C) \\
A, B, C \in \mathbb{N}
\end{gathered}
$$

Maka model dari CP dari ketiga fungsi tujuan tersebut secara berturut-turut dengan mempertimbangkan bobot dari fungsi tujuan $(w)$ dapat dirumuskan:

1. Mengoptimalkan fungsi tujuan $f_{i}$

Dengan kendala

$$
\operatorname{Min}\left\{\sum_{i=1}^{A} w_{i}\left(\delta_{i}^{+}+\delta_{i}^{-}\right)^{p}\right\}^{\frac{1}{\mathrm{p}}}
$$

2. Meminimalkan fungsi tujuan $f_{j}$

$$
\begin{gathered}
f_{i}+\delta_{i}^{-}+\delta_{i}^{+}=f_{(i)} \\
i=1,2, \ldots, A \\
\delta_{i}^{+}, \delta_{i}^{-} \geq 0
\end{gathered}
$$

Dengan kendala

$$
\operatorname{Min}\left\{\sum_{i=1}^{B} w_{j}\left(\delta_{j}^{+}\right)^{p}\right\}^{\frac{1}{p}}
$$

$$
\begin{gathered}
f_{j}-\delta_{j}^{+}=f_{j}^{\min } \\
\delta_{j}^{+} \geq 0, j=1,2, \ldots, B
\end{gathered}
$$

3. Memaksimalkan fungsi tujuan $f_{k}$

Dengan kendala

$$
\begin{array}{r}
\operatorname{Min}\left\{\sum_{k=1}^{C} w_{k}\left(\delta_{k}^{-}\right)^{p}\right\}^{\frac{1}{p}} \\
f_{k}+\delta_{k}^{-}=f_{k}^{\max } \\
\delta_{k}^{-} \geq 0, k=1,2, \ldots, C
\end{array}
$$

dengan $f_{(i)}$ adalah nilai fungsi sasaran dari tujuan ke- $i, f_{j}^{\text {min }}$ adalah nilai ideal minimum dari fungsi tujuan ke- $j, f_{k}^{\max }$ adalah nilai ideal maksimum dari fungsi tujuan ke- $k, \delta_{i}^{-}$adalah nilai deviasi negatif ke- $i, \delta_{i}^{+}$adalah nilai deviasi positif ke- $i, \delta_{j}^{+}$adalah nilai deviasi positif ke-j, $\delta_{k}^{-}$adalah nilai deviasi negatif ke- $k, P$ adalah nilai parameter, dan $A, B, C$ adalah banyaknya fungsi tujuan.

Dengan demikian model $C P$ untuk mengoptimalkan fungsi tujuan $A$, meminimalkan fungsi tujuan $B$ dan memaksimalkan fungsi tujuan $C$ secara umum dapat dirumuskan sebagai [4]:

$$
\operatorname{Min}\left\{\sum_{a=1}^{A} w_{a}\left(\delta_{a}^{+}+\delta_{a}^{-}\right)^{P}+\sum_{b=1}^{B} w_{b}\left(\delta_{b}^{+}\right)^{P}+\sum_{c=1}^{C} w_{c}\left(\delta_{c}^{-}\right)^{P}\right\}^{\frac{1}{P}}
$$

Dengan kendala

$$
\begin{gathered}
f_{a}+\delta_{a}^{-}-\delta_{a}^{+}=f_{(a)} \\
f_{b}-\delta_{b}^{+}=f_{b}^{\min } \\
f_{c}+\delta_{c}^{-}=f_{c}^{\max } \\
f_{(a)} \in \mathbb{R} \\
\delta_{a}^{+}, \delta_{a}^{-}, \delta_{b}^{+}, \delta_{c}^{-} \geq 0
\end{gathered}
$$


Dengan

$$
a=1,2, \ldots, A ; b=1,2, \ldots, B ; c=1,2, \ldots, C
$$

$$
\sum_{a=1}^{A} w_{a}+\sum_{b=1}^{B} w_{b}+\sum_{c=1}^{C} w_{c}=1\left(w_{a}, w_{b}, w_{c}>0\right)
$$

\section{Nadir Compromise Programming}

Metode Nadir Compromise Programming (NCP) merupakan pengembangan dari metode CP. Metode NCP ini pertama kali dipublikasikan pada tahun 2011 oleh Amiri et al. [4]. Berikut rincian dasar dari metode NCP [4]

1. Apabila optimisasi fungsi tujuan berdasarkan pada nilai fungsi sasaran ke- $k$, maka ditulis:

$$
\text { Optimisasi } f_{i}(i=1,2, \ldots, A)
$$

Apabila $f_{i} \in \mathbb{R}$ adalah nilai fungsi sasaran dari tujuan ke- $i$ dan $A$ adalah banyaknya fungsi tujuan, maka pada NCP hubungan antara fungsi tujuan ke- $i$ dan pembatas adalah:

$$
f_{i}=f_{(i)}
$$

Oleh sebab itu, pertidaksamaan dua sisi pembatas tersebut dapat dikonversikan sebagai dua pembatas $f_{(i)} \geq f_{i}$ dan $f_{(i)} \leq f_{i}$. Model NCP pada kondisi ini dengan mempertimbangkan bobot dari fungsi tujuan $\left(w_{i}\right)$, dapat dirumuskan sebagai:

$$
\operatorname{Min}\left\{\sum_{i=1}^{A} w_{i}\left(\delta_{i}^{+}+\delta_{i}^{-}\right)^{P}\right\}^{\frac{1}{P}}
$$

Dengan kendala

$$
\begin{gathered}
f_{i}-\delta_{i}^{+}=f_{(i)} \\
f_{i}+\delta_{i}^{-}=f_{(i)} \\
i=1,2, \ldots, A \\
\delta_{i}^{+}, \delta_{i}^{-} \geq 0
\end{gathered}
$$

2. Apabila tujuannya meminimalkan $f_{j}$ berdasarkan pada nilai nadir ke-j, maka:

$$
\operatorname{Min} f_{j}(j=1,2, \ldots, B)
$$

Misalkan $f_{j *}$ adalah nilai nadir dari tujuan ke-j, maka fungsi kendala untuk tujuan ke-j dalam metode NCP adalah $f_{j *} \geq f_{j}$. Oleh karena itu, model NCP pada kondisi ini dengan mempertimbangkan bobot dari fungsi tujuan $\left(w_{j}\right)$, dirumuskan sebagai:

$$
\operatorname{Min}\left\{\sum_{j=1}^{B} w_{j}\left(-\delta_{j}^{-}\right)^{P}\right\}^{\frac{1}{P}}
$$

Dengan kendala

$$
\begin{gathered}
f_{j}+\delta_{j}^{-}=f_{j *} \\
\delta_{j}^{-} \geq 0, j=1,2, \ldots, B
\end{gathered}
$$


3. Apabila tujuannya adalah untuk memaksimalkan $f_{k}$ berdasarkan pada nilai nadir ke- $k$, maka:

$$
\operatorname{Min} f_{k}(k=1,2, \ldots, C)
$$

dengan kendala untuk tujuan ini adalah $f_{k} \geq f_{k *}$. Dengan demikian model NCP dengan mempertimbangkan bobot dari fungsi tujuan $\left(w_{k}\right)$, dapat dirumuskan sebagai:

dengan kendala

$$
\operatorname{Min}\left\{\sum_{k=1}^{c} w_{k}\left(-\delta_{k}^{+}\right)^{P}\right\}^{\frac{1}{P}}
$$

$$
\begin{gathered}
f_{k}-\delta_{k}^{+}=f_{k *} \\
\delta_{k}^{+} \geq 0, k=1,2, \ldots, C
\end{gathered}
$$

Dengan demikian model NCP untuk mengoptimalkan fungsi tujuan A, meminimalkan fungsi tujuan B dan memaksimalkan fungsi tujuan $C$ secara umum dapat dirumuskan sebagai [4]:

$$
\operatorname{Min}\left\{\sum_{a=1}^{A} w_{a}\left(\delta_{a}^{+}+\delta_{a}^{-}\right)^{P}+\sum_{b=1}^{B} w_{b}\left(-\delta_{b}^{-}\right)^{P}+\sum_{c=1}^{C} w_{c}\left(-\delta_{c}^{+}\right)^{P}\right\}^{\frac{1}{P}}
$$

Dengan kendala

$$
\begin{gathered}
f_{a}-\delta_{a}^{+}=f_{(a)} \\
f_{a}+\delta_{a}^{-}=f_{(a)} \\
f_{b}+\delta_{b}^{-}=f_{b *} \\
f_{c}-\delta_{c}^{+}=f_{c *} \\
f_{(a)} \in \mathbb{R} \\
\delta_{a}^{+}, \delta_{a}^{-}, \delta_{b}^{-}, \delta_{c}^{+} \geq 0 \\
a=1,2, \ldots, A ; b=1,2, \ldots, B ; c=1,2, \ldots, C
\end{gathered}
$$

dengan

$$
\sum_{a=1}^{A} w_{a}+\sum_{b=1}^{B} w_{b}+\sum_{c=1}^{C} w_{c}=1\left(w_{a}, w_{b}, w_{c}>0\right)
$$

\section{Metode Analisis Data}

Data yang sudah terkumpul selanjutnya dianalisis hingga diperoleh kesimpulan akhir. Adapun langkahlangkah analisis dalam penelitian ini adalah sebagai berikut:

1. Perhitungan Return, Expected Return, Risiko, dan Rasio Setiap Saham

Data penelitian ini adalah harga saham mulai dari bulan Juni 2015 sampai dengan Mei 2017. Pengembalian atau return saham adalah sama dengan perubahan nilai saham dalam kurun waktu tertentu dibagi dengan nilai awal saham. Jika nilai return positif berarti saham tersebut memberikan keuntungan kepada kita, sebaliknya jika nilai return negatif maka saham tersebut memberikan keuntungan kepada kita. Sedangkan expected return merupakan return ekspektasi yang bisa kita dapatkan dengan menggunakan persamaan (3).

Setelah menghitung expected return masing-masing saham, kemudian dipilih saham-saham dengan nilai expected return yang positif. Selanjutnya hitung pula koefisien risiko dari masingmasing saham tersebut. Namun sebelum menghitung koefisien risiko, terlebih dahulu menghitung 
return pasar atau tingkat pengembalian pasar yang diwakili oleh Jakarta Islamic Index. Selanjutnya mengitung kovarian antara return saham dan return pasar yang bisa diperoleh dari persamaan (5). Langkah selanjutnya yaitu menghitung varian pasar menggunakan persamaan (4).

Setelah memperoleh nilai kovarian saham-return pasar dan varian pasar, kita bisa mencari nilai koefisien risiko.Koefisien risiko didapatkan dengan membandingkan kovarian saham-return pasar dengan varian pasar. Perhitungan koefisien risiko menggunakan persamaan (6). Setelah diperoleh risiko dari tiap-tiap saham, kemudian saham-saham tersebut dihitung rasionya dengan menggunakan persamaan:

$$
\text { Rasio }=\frac{E\left(R_{i}\right)}{\beta}
$$

setelah itu dipilih 6 saham dengan nilai rasio terbesar. Keenam saham inilah yang dipilih untuk pembentukan portofolio.

2. Perumusan Fungsi Tujuan dan Fungsi Kendala

Hal-hal yang diperhatikan pada optimasi portofolio ini adalah expected return, koefisien risiko, dan modal dana investasi. Sedangkan variabel output-nya adalah proporsi dana yang diinvestasikan pada masing-masing saham yang dilambangkan dengan $x_{i}$. Artinya $x_{i}$ adalah proporsi dana yang diinvestasikan pada saham ke-idengan $i=1,2,3, \ldots, 6$.

3. Menentukan Nilai Ideal dan Nilai Nadir dari Expected Return dan Dana Investasi Nilai ideal adalah nilai yang diperoleh dari kemungkinan solusi yang terbaik dan selanjutnya digunakan untuk membentuk model optimasi Compromise Programming, sedangkan nilai nadir adalah lawan dari nilai ideal.Nilai nadir diperoleh dari kemungkinan solusi terburuk dan selanjutnya digunakan untuk membentuk model optimasi Nadir Compromise Programming [3].

4. Perhitungan Proporsi Dana, Return, dan Risiko Menggunakan Compromise Programming dan Nadir Compromise Programming dengan bantuan software LINGO 14.

\section{Hasil dan Pembahasan}

\section{Perhitungan Return dan Expected Return}

Dari 30 saham yang terdaftar dalam Jakarta Islamic Index periode 1 April 2015 sampai 31 Mei 2017, dihitung nilai return dan expected return masing-masing saham. Setelah didapat nilai expected return masing-masing saham, kemudian dipilih saham-saham dengan nilai expected return yang positif.

Tabel 1 Nilai Expected Return Masing-masing Saham.

\begin{tabular}{llllll}
\hline No. & Nama Saham & $\boldsymbol{E}(\boldsymbol{R})$ & No. & Nama Saham & $\boldsymbol{E}(\boldsymbol{R})$ \\
\hline 1 & AALI & -0.000845223 & 16 & MIKA & -0.002675028 \\
2 & ADHI & 0.000136863 & 17 & MYRX & -0.002169511 \\
3 & ADRO & 0.002000920 & 18 & PGAS & -0.001222401 \\
4 & AKRA & 0.000834883 & 19 & PTBA & 0.000904058 \\
5 & ANTM & 0.001502751 & 20 & PTPP & -0.000060407 \\
6 & ASII & 0.000485666 & 21 & PWON & 0.000860564 \\
7 & BSDE & -0.000102905 & 22 & SILO & -0.000079799 \\
8 & ICBP & -0.000695727 & 23 & SMGR & -0.000570847 \\
9 & INCO & -0.000279917 & 24 & SMRA & -0.000312429 \\
10 & INDF & 0.000808857 & 25 & SSMS & 0.000098408 \\
11 & INTP & -0.000070597 & 26 & TLKM & 0.001237858 \\
12 & KLBF & -0.000211329 & 27 & UNTR & 0.001035502 \\
13 & LPKR & -0.001524755 & 28 & UNVR & 0.0006648496 \\
14 & LPPF & -0.000264102 & 29 & WIKA & -0.000517667 \\
15 & LSIP & 0.000270750 & 30 & WSKT & 0.001099253 \\
\hline
\end{tabular}


Tabel 2 Saham-saham dengan Nilai Expected Return Positif.

\begin{tabular}{llllll}
\hline No. & Nama Saham & $\boldsymbol{E}(\boldsymbol{R})$ & No. & Nama Saham & $\boldsymbol{E}(\boldsymbol{R})$ \\
\hline 1. & ADHI & 0.000136863 & 8. & PTBA & 0.000904058 \\
2. & ADRO & 0.002000920 & 9. & PWON & 0.000860564 \\
3. & AKRA & 0.000834883 & 10. & SSMS & 0.000009841 \\
4. & ANTM & 0.001502751 & 11. & TLKM & 0.001237858 \\
5. & ASII & 0.000485666 & 12. & UNTR & 0.001035502 \\
6. & INDF & 0.000808857 & 13. & UNVR & 0.000648496 \\
7. & LSIP & 0.000270750 & 14. & WSKT & 0.001099253 \\
\hline
\end{tabular}

\section{Perhitungan Koefisien Risiko}

Sebelum mendapatkan koefisien risiko masing-masing saham, terlebih dahulu hitung return pasar atau tingkat pengembalian pasar. Return pasar diwakili oleh Jakarta Islamic Index. Selanjutnya mengitung kovarian antara return saham dan return pasar yang bisa diperoleh dari persamaan (8). Nilai kovarianreturn pasar disajikan dalam tabel berikut:

Tabel 3 Nilai Kovarian Saham-Return Pasar.

\begin{tabular}{llllll}
\hline No. & Nama Saham & $\boldsymbol{C o v}\left(\boldsymbol{R}_{\boldsymbol{i}}, \boldsymbol{R}_{\boldsymbol{m}}\right)$ & No. & Nama Saham & $\boldsymbol{C o v}\left(\boldsymbol{R}_{\boldsymbol{i}}, \boldsymbol{R}_{\boldsymbol{m}}\right)$ \\
\hline 1 & ADHI & 0.000237858 & 8. & PTBA & 0.000435839 \\
2 & ADRO & 0.000443826 & 9. & PWON & 0.000280436 \\
3 & AKRA & 0.000071728 & 10. & SSMS & 0.000075582 \\
4 & ANTM & 0.000560778 & 11. & TLKM & 0.000178410 \\
5 & ASII & 0.000324014 & 12. & UNTR & 0.000203771 \\
6 & INDF & 0.000338311 & 13. & UNVR & 0.000241746 \\
7 & LSIP & 0.000287606 & 14. & WSKT & 0.000246239 \\
\hline
\end{tabular}

Langkah selanjutnya adalah menghitung varian pasar menggunakan persamaan (9). Sehingga dari persamaan tersebut diperoleh nilai varian pasar sebesar 0.000249715. Setelah diketahui nilai varian return pasar dan kovarian antara masing-masing saham dengan return pasar, maka dapat dihitung koefisien risiko masing-masing saham. Nilai koefisien risiko masing-masing saham didapatkan dengan menggunakan persamaan (10). Koefisien masing-masing saham disajikan dalam tabel berikut:

Tabel 4 Nilai Koefisien Risiko Saham.

\begin{tabular}{llllll}
\hline No. & Nama Saham & $\boldsymbol{\beta}$ & No. & Nama Saham & $\boldsymbol{\beta}$ \\
\hline 1 & ADHI & 0.952517115 & 8. & PTBA & 1.745348694 \\
2 & ADRO & 1.777333089 & 9. & PWON & 1.123024912 \\
3 & AKRA & 0.287239332 & 10. & SSMS & 0.302671848 \\
4 & ANTM & 2.245674079 & 11. & TLKM & 0.714457160 \\
5 & ASII & 1.297537895 & 12. & UNTR & 0.816014502 \\
6 & INDF & 1.354790515 & 13. & UNVR & 0.968089868 \\
7 & LSIP & 1.151739949 & 14. & WSKT & 0.986079394 \\
\hline
\end{tabular}

\section{Perhitungan Rasio Saham}

Setelah diketahui expected return dan risiko masing-masing saham, kemudian dihitung rasio dari tiaptiap saham tersebut dengan cara membandingkan antara expected return dan risiko. Rasio sahamsaham tersebut disajikan dalam tabel berikut: 
Tabel 5 Rasio Saham.

\begin{tabular}{llllll}
\hline No. & Nama Saham & $\frac{\boldsymbol{E}(\boldsymbol{R})}{\boldsymbol{\beta}}$ & No. & Nama Saham & $\frac{\boldsymbol{E}(\boldsymbol{R})}{\boldsymbol{\beta}}$ \\
\hline 1. & ADHI & 0.000143686 & 8. & PTBA & 0.000517981 \\
2. & ADRO & 0.001125799 & 9. & PWON & 0.000766291 \\
3. & AKRA & 0.002906576 & 10. & SSMS & 0.000032513 \\
4. & ANTM & 0.000669176 & 11. & TLKM & 0.001732585 \\
5. & ASII & 0.000374298 & 12. & UNTR & 0.001268975 \\
6. & INDF & 0.000597035 & 13. & UNVR & 0.000669872 \\
7. & LSIP & 0.000235079 & 14. & WSKT & 0.001114771 \\
\hline
\end{tabular}

Setelah didapat nilai rasio setiap saham, kemudian dipilih 6 saham dengan rasio tertinggi yang sekaligus digunakan untuk pembentukan portofolio. Keenam saham tersebut disajikan dalam tabel berikut:

Tabel 6 Saham-Saham Untuk Pembentukan Portofolio.

\begin{tabular}{ccccc}
\hline No. & Nama Saham & Expected Return & Risiko & Closing Price \\
\hline 1. & ADRO & 0.002000920 & 1.777333089 & 1520 \\
2. & AKRA & 0.000834883 & 0.287239332 & 6625 \\
3. & PWON & 0.000860564 & 1.123024912 & 610 \\
4. & TLKM & 0.001237858 & 0.714457160 & 4350 \\
5. & UNTR & 0.001035502 & 0.816014502 & 27775 \\
6. & WSKT & 0.001099253 & 0.986079394 & 2380 \\
\hline
\end{tabular}

\section{Perumusan Fungsi Tujuan dan Fungsi Kendala}

Model optimasi portofolio terdiri dari tiga aspek yaitu risiko, expected return dan modal investasi. Sedangkan variabel keputusannya adalah mendapatkan proporsi dana yang akan diinvestasikan pada masing-masing saham. Pendefinisian variabel keputusannya adalah sebagai berikut:

Tabel 7 Pendefinisian Variabel Keputusan.

\begin{tabular}{cll}
\hline Variabel & Kode & Nama Saham \\
\hline$x_{1}$ & ADRO & Adaro Energy Tbk. \\
$x_{2}$ & AKRA & AKR Corporindo Tbk. \\
$x_{3}$ & PWON & Pakuwon Jati Tbk. \\
$x_{4}$ & TLKM & Telekomunikasi Indonesia Tbk. \\
$x_{5}$ & UNTR & United Tractors Tbk. \\
$x_{6}$ & WSKT & Waskita Karya (Persero) Tbk. \\
\hline
\end{tabular}

Penentuan fungsi tujuan portofolio mempertimbangkan tiga aspek yaitu expected return, risiko, dan modal investasi yang dirumuskan sebagai berikut:

1. Fungsi tujuan optimum risiko

$$
o p t f_{1}=\sum_{i=1}^{6} \beta_{i} x_{i}
$$

2. Fungsi tujuan maksimasi expected return

$$
\operatorname{Max} f_{2}=\sum_{i=1}^{6} E\left(R_{i}\right) x_{i}
$$


3. Fungsi tujuan minimasi modal investasi

$$
\operatorname{Min} f_{3}=\sum_{i=1}^{6} P_{i} x_{i}
$$

Dalam memenuhi tujuan optimasi portofolio tersebut, ada beberapa kendala yang harus dipenuhi, antara lain:

1. Fungsi kendala jumlah proporsi dana

$$
\sum_{i=1}^{6} x_{i}=1
$$

2. Fungsi kendala batas bawah dan batas atas dana yang diinvestasikan

$$
0 \leq x_{i} \leq 0,8, i=1,2, \ldots, 6
$$

\section{Nilai Ideal dan Nilai Nadir Expected Return Portofolio}

Untuk portofolio yang terdiri dari 6 saham, maka nilai ideal expected return dapat dirumuskan sebagai berikut:

$$
\begin{gathered}
\operatorname{Max} 0.002000920 x_{1}+0.000834883 x_{2}+0.000860564 x_{3}+ \\
0.001237858 x_{4}+0.001035502 x_{5}+0.001099253 x_{6}
\end{gathered}
$$

Dengan kendala

$$
\begin{gathered}
x_{1}+x_{2}+x_{3}+x_{4}+x_{5}+x_{6}=1 \\
0 \leq x_{i} \leq 0,8 \quad, i=1,2, \ldots, 6
\end{gathered}
$$

Dengan $f_{2}$ adalah nilai ideal expected return pada 6 saham yang dibentuk pada portofolio, maka dengan menyelesaikan model di atas menggunakan LINGO 14 didapatkan $f_{2}=0.00184831$. Nilai Nadir merupakan kebalikan dari nilai ideal, sehingga dalam menyelesaikan permasalahan maksimasi expected return berdasarkan nilai nadir dapat dirumuskan sebagai berikut:

$$
\begin{gathered}
\operatorname{Min} 0.002000920 x_{1}+0.000834883 x_{2}+0.000860564 x_{3}+ \\
0.001237858 x_{4}+0.001035502 x_{5}+0.001099253 x_{6}
\end{gathered}
$$

Dengan kendala sama dengan persamaan (17).

Dengan $f_{2 *}$ adalah nilai nadir expected return pada 6 saham yang dibentuk pada portofolio, maka dengan menyelesaikan model di atas menggunakan LINGO 14 didapatkan $f_{2 *}=0.000840019$.

\section{Nilai Ideal dan Nilai Nadir Modal Investasi}

Untuk menghitung nilai ideal dan nilai nadir modal investasi diperlukan data closing price terakhir pada setiap saham. Data closing price tiap-tiap saham disajikan pada tabel 6. Untuk portofolio yang terdiri dari 6 saham, maka nilai ideal modal investasi dapat dirumuskan sebagai berikut:

$$
\operatorname{Min} 1520 x_{1}+6625 x_{2}+610 x_{3}+4350 x_{4}+27775 x_{5}+2380 x_{6}
$$

Dengan kendala sama dengan persamaan (17).

Dengan $f_{3}$ adalah nilai ideal modal investasi pada 14 saham yang dibentuk pada portofolio, maka dengan menyelesaikan model di atas menggunakan LINGO 14 didapatkan $f_{3}=792$. Sedangkan perhitungan untuk nilai nadir minimasi dana investasi adalah sebagai berikut: 
$\operatorname{Max} 1520 x_{1}+6625 x_{2}+610 x_{3}+4350 x_{4}+27775 x_{5}+2380 x_{6}$ dengan kendala sama dengan persamaan (17).

Dengan $f_{3 *}$ adalah nilai nadir modal investasi pada 6 saham yang dibentuk pada portofolio, maka dengan menyelesaikan model di atas menggunakan LINGO 14 didapatkan $f_{3 *}=23545$.

\section{Perhitungan Proporsi Dana dengan Compromise Programming}

Pada perhitungan Compromise Programming ini, bobot masing-masing fungsi tujuan $\left(W_{k}\right)$ dianggap sama untuk masing-masing fungsi tujuan. Karena jumlah total dari bobot fungsi tujuan sama dengan 1 , maka masing-masing fungsi tujuan memiliki bobot $\frac{1}{3}$ dengan rincian $\left(W_{1}\right)=\frac{1}{3}$ untuk risiko, $\left(W_{2}\right)=$ $\frac{1}{3}$ untuk expected return, dan $\left(W_{3}\right)=\frac{1}{3}$ untuk modal investasi. Sedangkan nilai $p$ diasumsikan sama dengan satu. Sehingga model compromise programming untuk masalah pemilihan portofolio adalah sebagai berikut:

Dengan kendala:

$$
\operatorname{Min}\left\{W_{1}\left(\delta_{1}^{+}+\delta_{1}^{-}\right)+W_{2}\left(\delta_{2}^{-}\right)+W_{3}\left(\delta_{3}^{+}\right)\right\}
$$

$$
\begin{gathered}
f_{1}+\delta_{1}^{-}-\delta_{1}^{+}=1 \\
f_{2}+\delta_{2}^{-}=f_{2} \\
f_{3}-\delta_{3}^{+}=f_{3} \\
x_{1}+x_{2}+x_{3}+x_{4}+x_{5}+x_{6}=1 \\
0 \leq x_{i} \leq 0,8 \quad, i=1,2, \ldots, 6 \\
\delta_{k}^{+} \geq 0, \delta_{k}^{-} \geq 0 \quad, k=1,2,3
\end{gathered}
$$

Dengan:

$W_{k}$ : bobot fungsi tujuan ke $-k, k=1,2,3$

$f_{k}$ : fungsi tujuan ke $-k, k=1,2,3$

$f_{l}$ : fungsi tujuan ke $-l$ berdasarkan nilai ideal, $l=1,2,3$

$x_{i}$ : proporsi dana yang diinvestasikan pada saham ke $-i, i=1,2, \ldots, 6$

$\delta_{k}^{+}$: deviasi positif dari fungsi tujuan ke $-k, k=1,2,3$

$\delta_{k}^{-}$: deviasi negatif dari fungsi tujuan ke $-k, k=1,2,3$

Setelah dilakukan perhitungan nilai ideal dari fungsi tujuan $f_{2}$ dan $f_{3}$ dan setelah model compromise programming dibentuk, langkah selanjutnya adalah menentukan variabel output yaitu menentukan proporsi dana yang diinvestasikan untuk masing-masing saham. Rumusan yang digunakan untuk mencari proporsi dana berdasarkan nilai ideal adalah sebagai berikut:

Dengan kendala:

$$
\operatorname{Min} \frac{1}{3} \delta_{1}^{-}+\frac{1}{3} \delta_{1}^{+}+\frac{1}{3} \delta_{2}^{-}+\frac{1}{3} \delta_{3}^{+}
$$

$$
\begin{gathered}
\sum_{i=1}^{6} \beta_{i} x_{i}-\delta_{1}^{+}+\delta_{1}^{-}=1 \\
\sum_{i=1}^{6} E\left(R_{i}\right) x_{i}+\delta_{2}^{-}=0.00184831 \\
\sum_{i=1}^{6} P_{i} x_{i}-\delta_{3}^{+}=792 \\
x_{1}+x_{2}+x_{3}+x_{4}+x_{5}+x_{6}=1 \\
0 \leq x_{i} \leq 0,8 \quad, i=1,2, \ldots, 6 \\
\delta_{k}^{+} \geq 0, \delta_{k}^{-} \geq 0 \quad, k=1,2,3
\end{gathered}
$$


Dengan $\beta_{i}$ adalah koefisien risiko, $E\left(R_{i}\right)$ adalah expected return, dan $P_{i}$ adalah closing price saham yang disajikan dalam tabel 6. Selanjutnya dengan menyelesaikan model Compromise Programming tersebut menggunakan LINGO 14, maka didapatkan hasil proporsi dana yang disajikan dalam tabel berikut.

Tabel 8 Proporsi Dana dari Metode Compromise Programming.

\begin{tabular}{cc}
\hline $\boldsymbol{x}_{\boldsymbol{j}}$ & Proporsi Dana \\
\hline$x_{1}$ & 0.2 \\
$x_{3}$ & 0.8 \\
\hline
\end{tabular}

Dari hasil proporsi dana saham-saham terpilih untuk membentuk portofolio yang optimal, maka dapat dihitung nilai $f_{1}^{*}, f_{2}^{*}, f_{3}^{*}$.

$$
\begin{aligned}
f_{1}^{*} & =\left(0.2 \times \beta_{1}\right)+\left(0.8 \times \beta_{3}\right) \\
& =(0.2 \times 1.777333089)+(0.8 \times 1.123024912) \\
f_{1}^{*} & =1.253886547 \\
f_{2}^{*} & =\left(0.2 \times E\left(R_{1}\right)\right)+\left(0.8 \times E\left(R_{3}\right)\right) \\
& =(0.2 \times 0.002000920)+(0.8 \times 0.000860564) \\
f_{2}^{*} & =0.001088635 \\
f_{3}^{*} & =\left(0.2 \times P_{1}\right)+\left(0.8 \times P_{3}\right) \\
& =(0.2 \times 1520)+(0.8 \times 610) \\
f_{3}^{*} & =792
\end{aligned}
$$

Hasil optimasi untuk pemilihan portofolio dengan menggunakan Compromise Programming adalah koefisien risiko optimal sebesar 1.253886547, expected return maksimal sebesar 0.001088635, dan dana investasi minimal 792.

\section{Perhitungan Proporsi Dana dengan Nadir Compromise Programming}

Pada perhitungan Nadir Compromise Programming ini, bobot masing-masing fungsi tujuan $\left(W_{k}\right)$ dianggap sama untuk masing-masing fungsi tujuan. Karena jumlah total dari bobot fungsi tujuan sama dengan 1, maka masing-masing fungsi tujuan memiliki bobot $\frac{1}{3}$ dengan rincian $\left(W_{1}\right)=\frac{1}{3}$ untuk risiko, $\left(W_{2}\right)=\frac{1}{3}$ untuk expected return, dan $\left(W_{3}\right)=\frac{1}{3}$ untuk modal investasi. Sedangkan nilai $p$ diasumsikan sama dengan satu. Sehingga model nadir compromise programming untuk masalah pemilihan portofolio adalah sebagai berikut:

$$
\operatorname{Min}\left\{W_{1}\left(\delta_{1}^{+}+\delta_{1}^{-}\right)+W_{2}\left(-\delta_{2}^{+}\right)+W_{3}\left(-\delta_{3}^{-}\right)\right\}
$$

Dengan kendala:

$$
\begin{gathered}
f_{1}+\delta_{1}^{-}=1 \\
f_{1}-\delta_{1}^{+}=1 \\
f_{2}-\delta_{2}^{+}=f_{2 *} \\
f_{3}+\delta_{3}^{-}=f_{3 *} \\
x_{1}+x_{2}+x_{3}+x_{4}+x_{5}+x_{6}=1 \\
0 \leq x_{i} \leq 0,8 \quad, i=1,2, \ldots, 6 \\
\delta_{k}^{+} \geq 0, \delta_{k}^{-} \geq 0 \quad, k=1,2,3
\end{gathered}
$$

Dengan:

$W_{k}$ : bobot fungsi tujuan ke $-k, k=1,2,3$

$f_{k}$ : fungsi tujuan ke $-k, k=1,2,3$

$f_{l}$ : fungsi tujuan ke $-l$ Berdasarkan nilai ideal, $l=1,2,3$ 
$x_{i}$ : proporsi dana yang diinvestasikan pada saham ke $-i, i=1,2, \ldots, 6$

$\delta_{k}^{+}$: deviasi positif dari fungsi tujuan ke $-k, k=1,2,3$

$\delta_{k}^{-}$: deviasi negatif dari fungsi tujuan ke $-k, k=1,2,3$

Setelah dilakukan perhitungan nilai nadir dari fungsi tujuan $f_{2 *}$ dan $f_{3 *}$ dan setelah model nadir compromise programming dibentuk, langkah selanjutnya adalah menentukan variabel outputyaitu menentukan proporsi dana yang diinvestasikan untuk masing-masing saham. Rumusan yang digunakan untuk mencari proporsi dana berdasarkan nilai ideal adalah sebagai berikut:

$$
\operatorname{Min} \frac{1}{3} \delta_{1}^{-}+\frac{1}{3} \delta_{1}^{+}-\frac{1}{3} \delta_{2}^{+}-\frac{1}{3} \delta_{3}^{-}
$$

Dengan kendala:

$$
\begin{gathered}
\sum_{i=1}^{6} \beta_{i} x_{i}+\delta_{1}^{-}=1 \\
\sum_{i=1}^{6} \beta_{i} x_{i}-\delta_{1}^{+}=1 \\
\sum_{i=1}^{6} E\left(R_{i}\right) x_{i}-\delta_{2}^{+}=0.000840019 \\
\sum_{i=1}^{6} P_{i} x_{i}+\delta_{3}^{-}=23545 \\
x_{1}+x_{2}+x_{3}+x_{4}+x_{5}+x_{6}=1 \\
0 \leq x_{i} \leq 0,8 \quad, i=1,2, \ldots, 6 \\
\delta_{k}^{+} \geq 0, \delta_{k}^{-} \geq 0 \quad, k=1,2,3
\end{gathered}
$$

Dengan $\beta_{i}$ adalah koefisien risiko, $E\left(R_{i}\right)$ adalah expected return, dan $P_{i}$ adalah closing price saham yang disajikan dalam tabel 5.6. Selanjutnya dengan menyelesaikan model Nadir Compromise Programming tersebut menggunakan LINGO 14, maka didapatkan hasil proporsi dana yang disajikan dalam tabel berikut.

Tabel 9 Proporsi Dana dari Metode Nadir Compromise Programming.

\begin{tabular}{ll}
\hline $\boldsymbol{x}_{\boldsymbol{j}}$ & Proporsi Dana \\
\hline$x_{2}$ & 0.1368494 \\
$x_{3}$ & 0.8 \\
$x_{6}$ & 0.0631506 \\
\hline
\end{tabular}

Dari hasil proporsi dana saham-saham terpilih untuk membentuk portofolio yang optimal, maka dapat dihitung nilai $f_{1}^{*}, f_{2}^{*}, f_{3}^{*}$.

$$
\begin{aligned}
f_{1}^{*}= & \left(0.1368494 \times \beta_{2}\right)+\left(0.8 \times \beta_{3}\right)+\left(0.0631506 \times \beta_{6}\right) \\
= & (0.1368494 \times 0.287239332)+(0.8 \times 1.123024912) \\
& +(0.0631506 \times 0.986079394) \\
f_{1}^{*}= & 1 \\
f_{2}^{*}= & \left(0.1368494 \times E\left(R_{2}\right)\right)+\left(0.8 \times E\left(R_{3}\right)\right)+\left(0.0631506 \times E\left(R_{6}\right)\right) \\
= & (0.1368494 \times 0.000834883)+(0.8 \times 0.000860564) \\
\quad & \quad(0.0631506 \times 0.001099253) \\
f_{2}^{*}= & 0.000872122
\end{aligned}
$$




$$
\begin{aligned}
f_{3}^{*} & =\left(0.1368494 \times P_{2}\right)+\left(0.8 \times P_{3}\right)+\left(0.0631506 \times P_{6}\right) \\
& =(0.1368494 \times 6625)+(0.8 \times 610)+(0.0631506 \times 2380) \\
f_{3}^{*} & =1545
\end{aligned}
$$

Hasil optimasi untuk pemilihan portofolio dengan menggunakan Nadir Compromise Programming adalah koefisien risiko optimal sebesar 1 , expected return maksimal sebesar 0.000872122 , dan dana investasi minimal 1545.

\section{Kesimpulan}

Dari hasil optimasi 6 saham pada bulan April 2015 sampai Mei 2017 dengan metode Compromise Programming dan Nadir Compromise Programming diperoleh proporsi dana untuk saham yang optimal adalah sebagai berikut:

Tabel 10 Saham Optimal.

\begin{tabular}{ll}
\hline Saham Optimasi & Saham Optimasi \\
Berdasarkan Metode Compromise Programming & Berdasarkan Metode Nadir Compromise Programming \\
\hline 1. ADRO proporsi dana 0.2 & 1. AKRA proporsi dana 0.1368494 \\
2. PWON proporsi dana 0.8 & 2. PWON proporsi dana 0.8 \\
\hline
\end{tabular}

Metode NCP lebih baik dibandingkan dengan metode CP karena sesuai dengan fungsi tujuan yang pertama yaitu mengoptimalkan koefisien risiko $(\beta)$, bahwa dengan menggunakan metode NCP risiko yang diperoleh mencapai optimal, sedangkan dengan menggunakan metode CP risiko yang diperoleh lebih besar yaitu 1.253886547. Koefisien risiko yang sama dengan 1 menandakan koefisien risiko NCP memiliki pergerakan yang sama dengan risiko pasar (JII) yang mengakibatkan hasil atau return yang didapat wajar dan tidak menyebabkan kerugian yang besar. Untuk fungsi tujuan yang kedua yaitu memaksimalkan return, metode CP lah yang terbaik karena return yang diperoleh lebih besar dibandingkan dengan metode NCP yaitu 0.001088635 untuk CP dan 0.000872122 untuk NCP. Sedangkan untuk modal investasi yang dihasilkan dengan metode CP lebih rendah dibandingkan modal investasi dengan metode NCP yaitu sebesar 792 untuk CP dan 1545 untuk NCP.

Dalam melakukan investasi setiap investor memiliki beberapa pertimbangan. Pada tugas akhir ini pertimbangan yang digunakan adalah mengoptimalkan koefisien risiko, memaksimalkan return dan meminimalkan modal investasi, sehingga metode yang memenuhi adalah metode NCP karena dalam metode ini koefisien risiko yang optimal bisa tercapai. Perbedaan yang paling mendasar dari kedua metode ini adalah jika metode CP mempertimbangkan solusi dari nilai ideal (kondisi terbaik), sedangkan metode NCP mempertimbangkan solusi dari nilai anti-ideal atau nilai nadir (kondisi terburuk).

\section{Referensi}

[1] Tandelilin, Eduardus. 2010. Portofolio dan Investasi, Teori dan Aplikasi. Yogyakarta: Kanisius.

[2] Susilo, Bambang D. 2009. Pasar Modal, Mekanisme Perdagangan Saham, Analisis Sekuritas, dan Strategi Investasi di Bursa Efek Indonesia (BEI). Yogyakarta: UPP STIM YKPN.

[3] Khoiri, Halwa Annisa. 2014. Perbandingan Compromise Programming dan Nadir Compromise Programming untuk Optimasi Multi-Objective Pada Pemilihan Portofolio Saham. http://digilib.its.ac.id/ITS-paper-12021140005693/33578. Diakses pada tanggal 10 Oktober 2016.

[4] Amiri, M., Ekhtiari, M., \& Yazdani, M. 2011. Nadir Compromise Programming: A Model For Optimization Of MultiObjective Portofolio Problem. Expert System with Applications, Vol. 38, No. 6, pp 7222-7226.

[5] Sholihin, Ahmad Ifham. 2010. Pedoman Lembaga Keuangan Syariah. Jakarta: PT. Gramedia Pustaka Utama.

[6] Suryomurti, Wiku. 2011. Supercerdas Investasi Syariah. Jakarta: Qultum Media.

[7] Husnan, Suad. 2003. Dasar-dasar Teori Portofolio. Edisi Kedua. Yogyakarta: UPP AMP YKPN.

[8] Reilly, F.K. \& Brown, K.C. 2011. Investment Analysis \& Portofolio Management. USA: South-Western Cengage Learning. 